\title{
BODY CONDITION OF COWS IN PRODUCTION CYCLE
}

\section{Ž. Novaković, Lj. Sretenović, S. Aleksić, M. M. Petrović V. Pantelić, D. Ostojić-Andrić, D. Nikšić}

Institute for Animal Husbandry, 11080, Belgrade-Zemun, Republic of Serbia

Corresponding author: zeljko.novakovic013@gmail.com

Original scientific paper

\begin{abstract}
Condition of animals is manifested through level of achieved nourishment. Body condition score (BCS) is a precise method of determination of reserves of deposited energy in form of subcutaneous fat tissue. Adequate body reserves are necessary requirement for maximal increase of milk production in the period of early lactation. Based on BCS we can precisely determine the number of cows which are bellow weight (excessively thin) or over weight (excessively fat). Body condition changes during lactation. Cows in early lactation are in the negative energy balance (NEB). Changes of the body condition should be over at the end of lactation. Objective is to have cows in optimal body condition during all production phases. Object of research was body condition of high yielding cows during production cycle. Realized sample size was 363 cows of Holstein-Friesian breed. Average BCS value of cows in dry period was 3.39 (2.37-4.41), at calving $3.56(2.55-4.63)$, at lactation peak $2.30(1.35-3.16)$ and in the mid lactation 2.50 (1.35-3.43). In dry period, most of cows $(\mathrm{n}=100$ or $27.55 \%)$ ranged in BCS from 3.26 to 3.50. During dry period increase of body condition scores of cows occurred. At calving, most of heads ( $\mathrm{n}=99$ or $27.50 \%$ ) ranged in their BCS from 3.51 to 3.75. During period of early lactation there was a significant decrease of the body condition of cows. At the peak of lactation a slight increase of body condition was recorded. At the peak of lactation, most cows $(n=125$ or $36.76 \%)$ ranged in BCS from 2.26 to 2.50 . In the mid-lactation period, slight increase of body condition of cows occurred. During this period, most cows ( $\mathrm{n}=88$ or $27.32 \%$ ) ranged in their BCS from 2.51 to 2.75 . In general, realized average BCS results according to production phases deviated statistically significantly from target values.
\end{abstract} balance.

Key words: Nutrition, production cycle, body condition score, energy 


\section{Introduction}

Balance between the requirements of the animal organism and possibility to intake nutrients through food are decisive factors which determine creation or loss of body reserves. Condition of animals is manifested through level of their state of nourishment. Body condition score (BCS) is a precise method for determination of fat reserves or quantity of energy in form of subcutaneous fat tissue deposited in the area around hips, loins and tail root. Amount of body reserves which cow has prior to calving has very strong impact on incidence of potential problems after calving, problems relating to milk production, reproduction efficiency and health condition (Bertics et al.,1992; Grummer, 1995; Drackley, 1999).

Cows are supposed to deposit in their own organism sufficient quantities of energy. Adequate body reserves are prerequisite/condition for maximum increase of milk production during the period of early lactation. It is not preferable that animals have excessive fat tissue reserves which will be used intensively at the beginning of lactation. Too rapid change of body condition leads to problems. Risk of problems occurring at calving is reduced when cows are in optimum body condition for that specific phase of production cycle (Wildman et al., 1982; Edmonson et al., 1989; Ferguson, 1989; Otto et al., 1991; Ruegg and Milton, 1995).

BCS at calving effects production of milk during lactation. If BCS is low, milk yield at the peak of lactation will also be low. In addition, problems in reproduction will occur. If cows are overweight, metabolic problems can be expected. Cows in poor body condition prior to calving $(\mathrm{BCS} \leq 3.00)$ experience decrease in milk production during early lactation, problems with various metabolic disorders (ketosis, dislocation of abomazus) and delayed onset of production cycle. Very often premature culling from herd occurs, which shortens life and production lifetime. Consequence is significant decrease of the genetic progress and economical efficiency of the production.

Loss of body condition leads to decrease of quantity of milk in current standard lactation (Waltner et al., 1993; Pedron et al., 1993). During the period of early lactation cows shouldn't loose more than 1.00 BCS. Body reserves are most important for support in production of milk for that period. Normalization of the situation in reproduction starts with restoring and establishing of balance in maintenance of body mass.

Based on BCS we can precisely determine the percentage of cows which are excessively thin/underweight or excessively thick/overweight. Level of BCS of remaining cows should be within optimum value and adequate to the production phase. Cows are thin during dry period if BCS is bellow 3.00. Cows are considered thick if score exceeds 3.75. Other cows should be within preferable BCS. Total of 
70 to $80 \%$ of cows should be within optimum BCS range. If there are over $15 \%$ of cows in extreme categories, then we know that problems are present. Increase of the said percentage requires implementation of corrective measures in the technological process. Ideal body condition is a rank in the function of flow and lactation stage (Ferguson et al., 1994).

Objective is to have cows in optimum condition at calving which are not too thin or too thick. Body condition changes during lactation cycle. Cows in early lactation experience negative energy balance (NEB). Body condition is lost through mobilization of body reserves for the purpose of synthesis of milk. Cows in late lactation are in the positive energy balance. This is the period when they restore body reserves used up during early lactation. Changes of the body condition should end with the completion of lactation.

Assessment of body condition of cows is functional method. It is unavoidable and principal part of the farm management strategy. Monitoring of the body condition is reliable indicator of the energy status of cows in transitional period. With the increase of production of milk also utilization of body reserves increase which is used for synthesis of milk. With regular evaluation of cows we create conditions for predicting and identifying of problems before they are manifested. BCS should be main component of the programs of monthly controls and basis for corrective activities in herd management (Grubić et al., 2009).

During dry period, cows cannot gain nor loose on body condition. In the period of high gravidity energy balance is positive. This is a period which includes end of lactation and dry period. Recommended BCS for cows after calving is 3.50 (3.25-3.75). It is necessary that an animal reaches this assessment level in the period of late lactation. Optimum BCS at the moment of calving is 3.50 (3.253.75). Body reserves prepared in the previous period are used for milk synthesis. Cows in first 100 to 120 days of lactation should have BCS from 2.50 to 3.25. This is necessary requirement for efficient production of milk, good health and reproductive status of cows in current lactation. BCS $<2.50$ is associated with low production of milk because of insufficient energy in diet (Hady et al.,1994). Great loss of body condition was recorded in 13 herds with BCS of 0.80 in the period of 50 to 80 days (Ruegg and Milton,1995). Loss of body condition during postpartum period in first lactating cows was $0.30 \mathrm{BCS}$, and cows in the second lactation had BCS 0.29 OTK (Dechow et al., 2002). Early lactation is the most critical period in production cycle of high yielding cows.

From the peak of lactation until new dry period, cows have to renew their body reserves. Energy balance 10 to 12 weeks after calving is positive again and animals start to build their body reserves. Nutrition in this period should provide for start of restoring of body condition. It is important to avoid fattening condition. In high yielding cows, during the mid-lactation period (101-200 days) optimum BCS is $3.00(2.75-3.25)$. During the period of late lactation, optimum BCS is 3.25 
(3.00-3.75). Balancing of food is the way to improve the body condition for next lactation.

Control of BCS of cows is very important. It is necessary to avoid fattening condition of cows. BCS of $<3.00$ indicates low level of energy in diet. Consequences are problems occurring during early lactation period. Surplus of energy in diet with extended interval between calving (MTI) can lead to BCS which is $>3.75$. At the end of lactation ( $>300$ days) before onset of dry period, optimum BCS is $3.50(3.25-3.75)$. It is important to save/maintain the condition during dry period in all cows. This refers also to cows in fattening condition. BCS of cows has to be improved and brought to optimum level before dry period.

\section{Materials and Methods}

Objective of the study was BCS of high yielding cows in production cycle. Studied sample consisted of 363 Holstein-Friesian cows. Average milk production in standard lactation of these cows in recent years was 7500 kilograms. All animals included in the study sample were reared in the same housing system (tie system), nutrition (complete mixture and concentrate supplements according to milk yield), care, health protection and exploitation.

According to research plan, body condition was visually assessed using standards defined for each phase of production cycle (Edmonson et al., 1989). Each Cow was assessed:

1. at the beginning of dry period,

2. two days after calving,

3. the peak of lactation (40. day) and

4. mid-lactation (150. day).

BCS system for high yielding cows is created in the form of map (chart). Map is precisely prepared for each body region and area (field). It includes all body regions and areas which are considered to be important in the allocation of total BCS for a cow. Three large body regions are defined: loins, pelvis and tail root. Within all three regions on the body of the cow there is total of 8 areas/fields. Loins have 4 fields, pelvis 3 and tail root 1 .

Each animal is assessed individually. Every body field/are within regions is assessed separately. Assessment of these areas/fields is indicator of body condition. BCS range from the minimal score of 1 to the maximal score of 5 . For changes of the level of BCS scale is used with continuous increase of 0.25 of the score. Whole BCS system functions on the basis of 17 score levels within stated score range. Under weight condition corresponds to score 1, whereas extremely fattening 
condition is given score 5. Each stage of the production cycle has its own optimal score.

Data base for implemented BCS system was analyzed using adequate mathematical-statistical methods. Information on results of the research are presented in table using basic indicators of descriptive statistics (arithmetic mean, extreme values, standard deviation, variation coefficient). Significance of difference between obtained means in scoring of body condition and target body condition score was verified using t-test. Experimental results were statistically analyzed using package STATISTICA v. 6. StatSoft, Inc. (2003).

\section{Results and Discussion}

Results obtained in the study of BCS of cows in production cycle are presented using basic indicators of descriptive statistics. Established results are presented in following tables and graphs.

Table 1. Average BCS of cows according to stages of the production cycle

\begin{tabular}{|c|c|c|c|c|}
\hline \multirow{2}{*}{ Indicators } & \multicolumn{4}{|c|}{ Average BCS } \\
\cline { 2 - 5 } & \multicolumn{4}{|c|}{ Stage of production cycle } \\
\cline { 2 - 5 } & 1 & 2 & 3 & 4 \\
\hline $\bar{N}$ & 3.39 & 3.56 & 2.30 & 2.50 \\
\hline $\mathrm{n}$ & 363 & 360 & 340 & 322 \\
\hline $\mathrm{Max}$ & 4.41 & 4.63 & 3.16 & 3.43 \\
\hline $\mathrm{Min}$ & 2.37 & 2.55 & 1.35 & 1.35 \\
\hline $\mathrm{Sd}$ & 0.37 & 0.38 & 0.27 & 0.35 \\
\hline $\mathrm{Sx}$ & 0.022 & 0.022 & 0.017 & 0.021 \\
\hline $\mathrm{Cv}$ & 11.01 & 10.77 & 11.82 & 14.10 \\
\hline $\mathrm{p}$ & 0.000 & 0.000 & 0.000 & 0.000 \\
\hline
\end{tabular}

Presented results precisely indicate realized average values, variation interval, standard deviation, variation coefficient and significance of deviations of realized BCS from target BCS according to stages of production cycle (Table 1). Average value of BCS of cows in dry period was 3.39 (2.37-4.41), at calving 3.56 (2.55-4.63), at the lactation peak 2.30 (1.35-3.16) and mid-lactation 2.50 (1.35$3.43)$. 


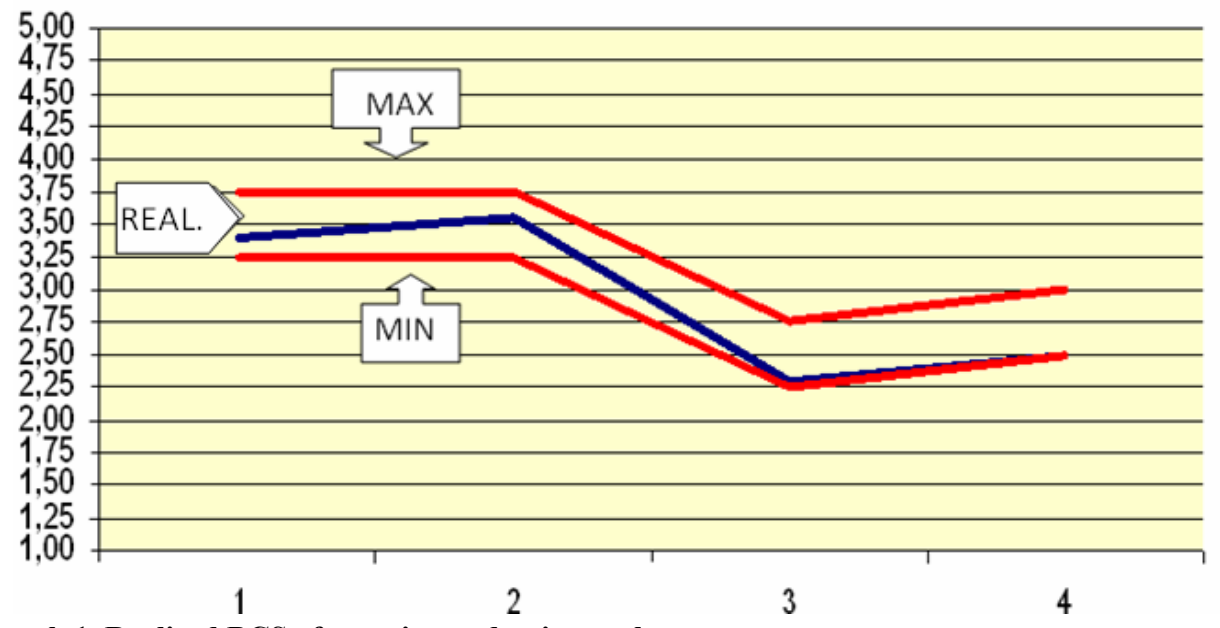

Graph 1. Realized BCS of cows in production cycle

Table 2. Distribution of BCS of cows according to stages of production cycle

\begin{tabular}{|c|c|c|c|c|}
\hline \multirow{3}{*}{$\mathrm{BCS}$} & \multicolumn{4}{|c|}{ Number of animals } \\
\hline & \multicolumn{4}{|c|}{ Stage of production cycle } \\
\hline & 1 & 2 & 3 & 4 \\
\hline $1.00-1.25$ & 0 & 0 & 0 & 0 \\
\hline $1.26-1.50$ & 0 & 0 & 1 & 1 \\
\hline $1.51-1.75$ & 0 & 0 & 2 & 5 \\
\hline $1.76-2.00$ & 0 & 0 & 43 & 16 \\
\hline $2.00-2.25$ & 0 & 0 & 84 & 54 \\
\hline $2.26-2.50$ & 1 & 0 & 125 & 85 \\
\hline $2.51-2.75$ & 11 & 5 & 69 & 88 \\
\hline $2.76-3.00$ & 40 & 21 & 14 & 43 \\
\hline $3.01-3.25$ & 79 & 47 & 2 & 25 \\
\hline $3.26-3.50$ & 100 & 94 & 0 & 5 \\
\hline $3.51-3.75$ & 77 & 99 & 0 & 0 \\
\hline $3.76-4.00$ & 36 & 49 & 0 & 0 \\
\hline 4.01-4.25 & 17 & 34 & 0 & 0 \\
\hline $4.26-4.50$ & 2 & 10 & 0 & 0 \\
\hline $4.51-4.75$ & 0 & 1 & 0 & 0 \\
\hline $4.76-5.00$ & 0 & 0 & 0 & 0 \\
\hline $\mathrm{n}$ & 363 & 360 & 340 & 322 \\
\hline
\end{tabular}




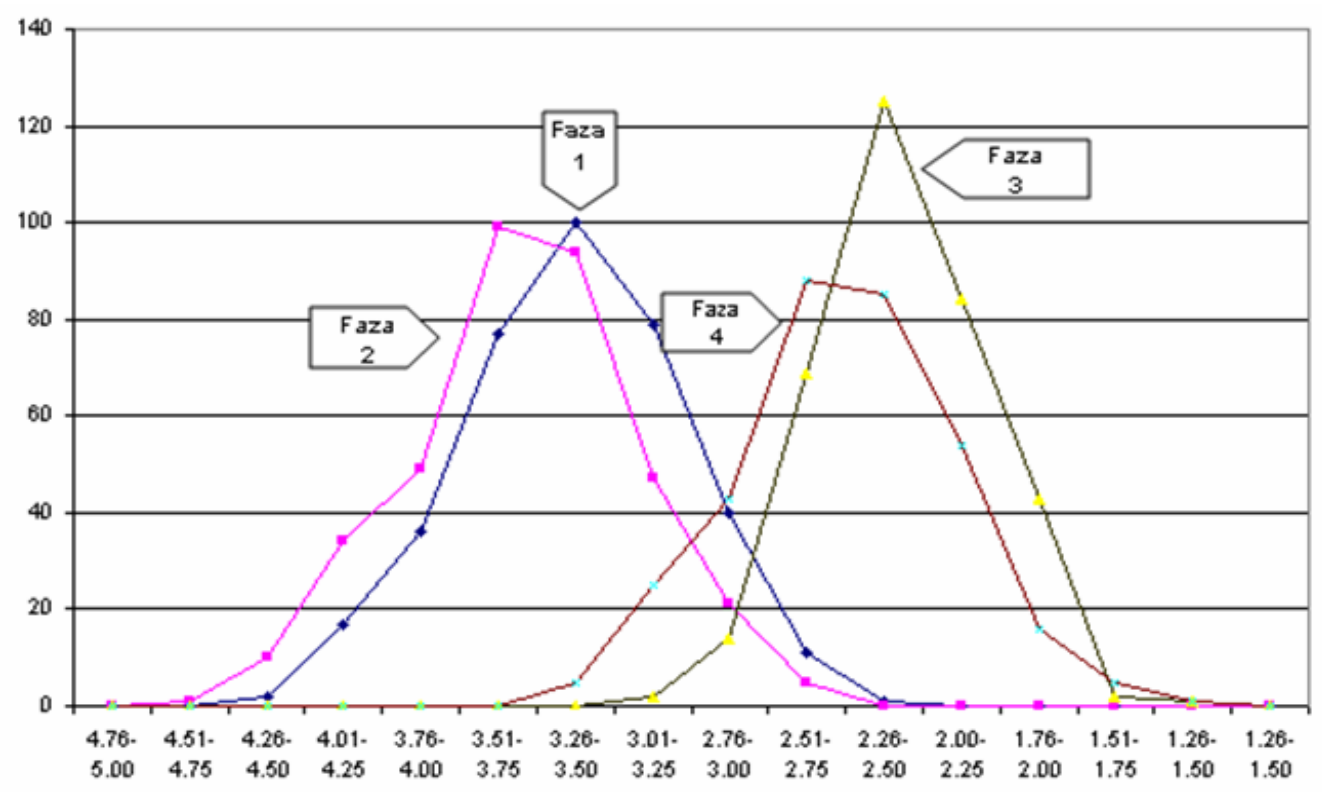

Graph 2. Distribution of BCS of cows according to stages of production cycle

Realized values indicated that in distribution of average BCS of cows in the first stage of production cycle, of the total number of animals - 363, most of cows ( $\mathrm{n}=100$ or $27.55 \%$ ) ranged in their BCS from 3.26 to 3.50 (Table 2.). Bellow this BCS there were 131 animals or $36.09 \%$, and above 132 animals or $36.36 \%$.

In the second stage of production cycle of total 360 evaluated cows, most animals ( $\mathrm{n}=99$ or $27.50 \%$ ) ranged with their BCS from 3.51 to 3.75 . Bellow this interval of BCS were 167 animals or $46.39 \%$, and above 84 animals or $23.33 \%$. It is necessary to mention that in this production stage 193 cows or $53.61 \%$. ranged in their BCS from 3.26 to 3.75. Above this level of BCS there were 94 animals or $26.11 \%$, whereas 73 cows or $20.27 \%$ were bellow this level. During dry period, within BCS distribution a move towards higher values occurred, which is result of increase of body condition of cows in this period.

In the third stage of 340 evaluated cows, most animals ( $\mathrm{n}=125$ or $36.76 \%$ ) ranged in their BCS from 2.26 to 2.50. Bellow stated BCS level there were 130 animals or $38.23 \%$, and above this level 85 cows or $25.00 \%$. During the period of early lactation and within the structure of BCS range, a move towards lower values was recorded as the result of decrease of body condition of cows.

In the fourth stage of production cycle, of total of 322 evaluated animals, most cows ( $\mathrm{n}=88$ or $27.32 \%$ ) ranged in their BCS from 2.51 to 2.75 . Bellow this level of BCS there were 161 animals or $50.00 \%$, and above 73 cows or $22.67 \%$. It is important to mention that in this production stage, 173 cows or $53.73 \%$ were in 
wide range of BCS from 2.26 to 2.75. Above this BCS level there were 73 animals or $22.67 \%$, whereas 76 cows or $23.60 \%$ were bellow this level. During the period of mid-lactation, within the structure of BCS range, a move towards higher values was recorded. In general, results deviated statistically significantly from target values for assessment of body condition of dairy cows.

Obtained results are similar to values for average BCS reported by Hady et al. (1994). Lower average values were obtained in researches of Ruegg and Milton, (1995). Higher values were obtained in the study by Dechow et al. (2002).

\section{Conclusion}

Based on research results it can be concluded that the body condition of high yielding cows often is outside the optimum values for certain stages of production cycle. Decrease of production, incidence of health and fertility disorders indicate the nature of existing connection between inadequate body condition and stated problems. Research indicates that based on implementation of method for assessment of body condition there is possibility to achieve more efficient management of changes in energy reserves of the cow organism. Method of body condition assessment is functional indicator of the nutrition status and energy balance in the cow organism. In addition, it shows that body condition of animal in all stages of production cycle is important indicator of applied nutrition and technological process in general. This further indicates great significance of the use of the method of body condition assessment in high yielding cows and need that it becomes part of everyday practice on cattle farms.

\section{Telesna kondicija krava u proizvodnom ciklusu}

Ž. Novaković, Lj. Sretenović, S. Aleksić, M. M. Petrović V. Pantelić, D. OstojićAndrić, D. Nikšić

\section{Rezime}

Prikazani rezultati precizno ukazuju na ostvarene prosečne vrednosti, interval varijacije, standardnu devijaciju, koeficijent varijacije i značajnost odstupanja postignutih od ciljnih vrednosti OTK krava po fazama proizvodnog ciklusa. Prosečna vrednost OTK krava iznosila je na zasušenju 3.39 (2.37-4.41), teljenju 3,56 (2,55-4,63), vrhu laktacije 2,30 $(1,35-3,16)$ i sredini laktacije 2,50 $(1,35-3,43)$. Realizovane vrednosti ukazuju da je kod distribucije prosečnih OTK krava za sve tri telesne regije u prvoj fazi proizvodnog ciklusa od ukupnog broja koji čini 363 grla najviše (n=100 ili 27,55\%) bilo u intervalu OTK od 3,26 do 3,50. 
Ispod tog intervala OTK bilo je 131 grlo ili $36,09 \%$, a iznad 132 grla ili $36,36 \%$. U drugoj fazi proizvodnog ciklusa od ukupno 360 ocenjenih krava najviše grla $(n=99$ ili $27,50 \%$ ) bilo je u intervalu OTK od 3,51 do 3,75. Ispod tog intervala OTK bilo je 167 grla ili $46,39 \%$, a iznad 84 grlo ili $23,33 \%$. U ovoj fazi poizvodnje u intervalu OTK od 3,26 do 3,75 bilo je 193 krave ili 53,61\%. Iznad tog nivoa OTK bilo je 94 grla ili 26,11\%, dok je ispod bilo 73 krave ili 20,27\%. Tokom perioda zasušenja došlo je do povećanja telesne kondicije krava. U trećoj fazi od 340 ocenjenih krava najviše grla ( $\mathrm{n}=125$ ili 36,76\%) bilo je u intervalu OTK od 2,26 do 2,50. Ispod navedenog nivoa OTK bilo je 130 grla ili $38,23 \%$, a iznad 85 krava ili $25,00 \%$. Tokom perioda rane laktacije došlo je do značajnog smanjenja telesne kondicije krava.U četvrtoj fazi proizvodnog ciklusa od ukupno 322 ocenjena grla najviše krava ( $\mathrm{n}=88$ ili $27,32 \%$ ) bilo je u intervalu OTK od 2,51 do 2,75. Ispod tog intervala OTK bilo je 161 grlo ili $50,00 \%$, a iznad 73 krave ili $22,67 \%$. U ovoj fazi poizvodnje u širem intervalu OTK od 2,26 do 2,75 bilo je 173 krave ili $53,73 \%$. Iznad tog nivoa OTK bilo je 73 grla ili 22,67\%, dok je ispod bilo 76 krava ili $23,60 \%$. U periodu sredine laktacije došlo je do blagog povećanja telesne kondicije krava. U celini posmatrano rezultati su statistički vrlo značajno su odstupali od ciljnih vrednosti za ocenu telesne kondicije

\section{References}

BERTICS S.J., GRUMMER R.R., CADORINGA-VALINO C., STODDARD E.E. (1992): Effect of prepartum dry matter intake on liver triglyceride concentration and early lactation. J. Dairy Sci., 75, 1914.

Body Condition Scoring in Dairy Cattle. Copyright by Elanco Animal Helth, 1997. DECHOW C.D. , ROGERS G.W., CLAY J.S. (2002): Heritability and Correlations Among Body Condition Score Loss, Body Condition Score, Production and Reproductive Performance, J. Dairy Sci., 85, 3062-3070

DRACKLEY J.K. (1999): Biology of Dairy Cows During the Transition Period: the Final Frontier. J Dairy Sci., 82, 2259-2273

EDMONSON A.J., LEAN I.J., WEAWER L. D., FARVER T., WEBSTER G. (1989): A body condition scoring chart of Holstein dairy cows. J. Dairy Sci., 72, 68. FERGUSON J.D. (1989): Implementation of a body condition scoring program in dairy herds. University of Pennsylvania.

FERGUSON J.D., GALLIGAN D.T., THOMSEN N. (1994): Principal Descriptors of Body Condition Score in Holstein Cows, J Dairy Sci, 77, 2695-2703.

GRUBIĆ G., NOVAKOVIĆ Ž., ALEKSIĆ S., SRETENOVIĆ Lj., PANTELIĆ V., OSTOJIĆ-ANDRIĆ D. (2009): Evaluation of the body condition of high yielding cows, Biotechnology in Animal Husbandry 25, 1-2, 81-91. 
GRUMMER R.R. (1995): Impact of changes in organic nutrient metabolism on feeding the transition cow. J. Anim. Sci., 73, 2820.

HADY P.J., DOMECQ J.J., KANEENE J.B.(1994):Frequency and in Dairy Cattle Precision of Body Condition Scoring, J Dairy Sci, 77, 1543-1547

OTTO K.L., FERGUSON J.D., FOX D.G., SNIFFEN C.J. (1991): Relationship Between Body Condition Score and Composition of Ninth to Eleventh Rib Tissue in Holstein Dairy Cows, J Dairy Sci, 74, 852-859.

PEDRON O., CHELI F., SENATORE E., BAROLI D., RIZZI R. (1993): Effect of body condition score at calving on performance, some blood parameters, and milk fatty acid composition in dairy cows. J. Dairy Sci,. 76, 2528-2535.

RUEGG P.L., MILTON R.L. (1995): Body condition scores of Holstein cows on Prince Edward Island, Canada: Relationship with yield, reproductive performance and disease. J Dairy Sci,78, 552-64.

WALTNER S.S., Mc NAMARA J.P., HILLERS J.K. (1993): Relationships of Body Condition Score to Production Variables in High Producing Holstein Dairy Cattle, J Dairy Sci, 76, 3410-3419.

WILDMAN E.E., JONES G.M., WAGNER P.E., BOWMAN R.L., TROUTT H.F., LESCH T.N. (1982): A dairy cow body condition scoring system and its relationship to selected production characteristics. J. Dairy Sci., 65, 495. 